\title{
EVALUATION OF THE 1OFFICE-INTEGRATED SYSTEM USING AN ADAPTATION TO THE DELONE AND MCLEAN SUCCESS MODEL
}

\author{
Bayu Dewantoro ${ }^{* 1}$, Irman Hermadi ${ }^{* *}$, and Joko Ratono $\left.{ }^{* * *}\right)$ \\ *) PT. Grundfos Indonesia \\ Jl. Cililitan Besar No.454, Halim, East Jakarta13650 \\ ${ }^{* *}$ Department of Computer Science, Faculty of Matematics and Natural Science, IPB University \\ Jl. Meranti, Campus IPB Dramaga Bogor 16680 \\ ${ }^{* * *}$ Department of Statistics, Faculty of Matematics and Natural Science, IPB University \\ Jl. Meranti, Campus IPB Dramaga Bogor 16680
}

\begin{abstract}
This study aimed to evaluate the successful implementation of 1Office integration system at PT Grundfos Indonesia by an adaptation to DeLone and McLean model. The 1Office is a system that should be applied in all Grundfos's companies, according to the instructions from its headquarter. There are 6 variables to evaluate in the DeLone and McLean model, namely Service Quality, System Quality, Information Quality, Use, User Satisfaction and Net Benefits. Using a quantitative approach, questionnaires were used as a technique for data collection. The data obtained then was analyzed using SEM PLS (Structural Equation Modeling Partial Least Square) and purposive sampling on 60 users. The results showed that Service Quality has a positive effect on Use and User Satisfaction, so does System Quality on User Satisfaction. Furthermore, User Satisfaction has a positive influence on Net Benefits as the effectiveness of using information systems, which has an impact on user groups, organisations, suppliers, and customers at PT. Grundfos Indonesia.
\end{abstract}

Keywords: 1Office system, DeLone and McLean model, PT Grundfos Indonesia, SEM PLS

Abstrak: Penelitian ini bertujuan mengevaluasi keberhasilan implementasi dari sistem integrasi 1 Office yang terjadi di PT Grundfos Indonesia dengan menggunakan adaptasi model sukses DeLone dan McLean. Sistem 1Office adalah sistem yang wajib diimplementasikan di semua perusahaan Grundfos sesuai instruksi dari head quarter. Model DeLone dan McLean memiliki 6 variabel yang akan dievaluasi yaitu: kualitas layanan, kualitas sistem, kualitas informasi, penggunaan, kepuasan pengguna dan keuntungan bersih. Penelitian ini menggunakan pendekatan kuantitatif dengan kuesioner sebagai teknik pengumpulan data, analisis data menggunakan SEM PLS (Structural Equation Modeling Partial Least Square) serta purposive sampling terhadap 60 pengguna. Hasil penelitian menunjukkan bahwa kualitas layanan berpengaruh positif terhadap penggunaan dan kepuasan pengguna, kualitas sistem berpengaruh positif terhadap kepuasan bagi pengguna. Selanjutnya, kepuasan pengguna memberikan pengaruh positif terhadap manfaat bersih yang merupakan keefektifan dalam menggunakan sistem informasi dan dapat memberikan dampak terhadap grup pengguna, organisasi, pemasok serta pelanggan di PT. Grundfos Indonesia.

Kata kunci: 1Office system, DeLone dan McLean model, PT Grundfos Indonesia, SEM PLS

${ }^{1}$ Corresponding author:

Email: donbayu@gmail.com 


\section{INTRODUCTION}

Therapid developmentofInformation Systems, having an impact on the development of Communication Systems, has been underlying companies or corporations to adopt appropriate Communication Systems. They get benefits both in financing and operations because there are many choices to meet everything needed in communication. In addition to helping the company's routine operations to become more efficient, information systems are also a major competitive differentiating factor (O'Brien, 2006). In the past, the centralized communication systems were dominated by analog technology, which is now still used by several companies. In line with the development of Information Systems and their use in communication technology, a communication system applicable to information systems, namely IP-based communication technology, has been introduced.

PT. Grundfos Indonesia is a company that has implemented an IP-based communication system. It is engaged in selling and manufacturing pumps and targeting households and industries as its market shares. As a subsidiary, all policies and procurements to meet its business needs, including the implementation of technology and communication, are done under the direction of the parent company, namely Grundfos Management A/S domiciled in Denmark. The type of communication technology it uses is IP PBX or Internet Protocol Private Branch Exchange and the required facilities such as Voice mail, Voice Conference, Video Conference, Contact Centre, and other features that are considered necessary and following the needs of PT. Grundfos Indonesia. The system has been adapted integrally with one of the information technology applications, namely Customer Relationship Management, so-called 1Office.

This study examined the positive influence of the system quality, the information quality, and the system services on the use of the system, and the impact on user satisfaction. It also examined the system use and the users' satisfaction with the net benefits for the organisation. The system was implemented, following the instructions of the Grundfos headquarter to facilitate interaction and collaboration between the employees by providing a system that can track all telephone calls, both answered and unanswered, providing detailed reports to the activities of each agent, and being integral to the CRM (Customer Relationship Management) system. Perry (2006) stated that a review is needed to determine whether or not it has been operated as expected and has satisfied the user needs. Information systems are used by an organisation to help its operations become more efficient as a tool to win the competition.

1Office, like other global systems, gets services from the Global IS Service Desk to users 24/7 via time differences between countries. Grundfos Global IS Service Desk shared its service in 3 continents, namely Asia, Europe, and America, namely in the city of Manila (Philippines), Bjerringbro (Denmark), and Fresno (the US). Users of Grundfos have options to contact the Global IS Service Desk, namely the Intranet portal, telephone connection, or chatting facilities. This research was aimed at examining the extent of the success of the implementation, given the system implementation policy is a must, according to the instructions from the Grundfos headquarter, where each country has its local conditions. In general, this study was to analyse factors that have an impact on the organisation's net benefits.

Jogiyanto (2007) categorised previous studies into two groups. The first group is based on affective and cognitive behaviours, such as attitudes, norms, and perceptions of usage. Theories and models of studies regarding the dimensions of behavioural causes in the forms of affective and cognitive were Theory Reasoned Action (TRA) by Fishben and Ajzen (1975), Technology Acceptance Model (TAM) by Davis (1989), and Theory of Planned Behavior ( TPB) by Ajzen (1991). The second one is a group that have behavioural causes due to a process in the organisation, such as the processes of assessment, participation and involvement, and matching technology with its tasks. The popular model in the second group is a model by DeLone and McLean (1992). This model reflects the dependence of six measurements of information system success, namely system quality, information quality, user satisfaction, use, individual impact, and organisational impact), as illustrated in Figure 1.

Based on the criticism received and the development of information systems and their use environment, DeLone and McLean (2003) updated their model by expanding it (Jogiyanto, 2007). They added the variable 'service quality', changed the variables 'individual and organisational impacts' to 'net benefits', and added the dimension 'intention to use' as an alternative to 'use'. The updated DeLone and McLean models in 2003 are depicted in Figure 2. 


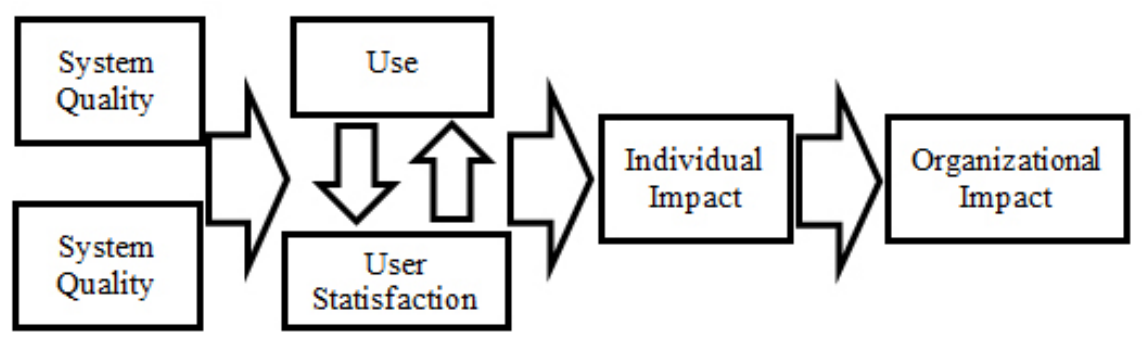

Figure 1. Delone \& McLean Information System Success Model (1992)

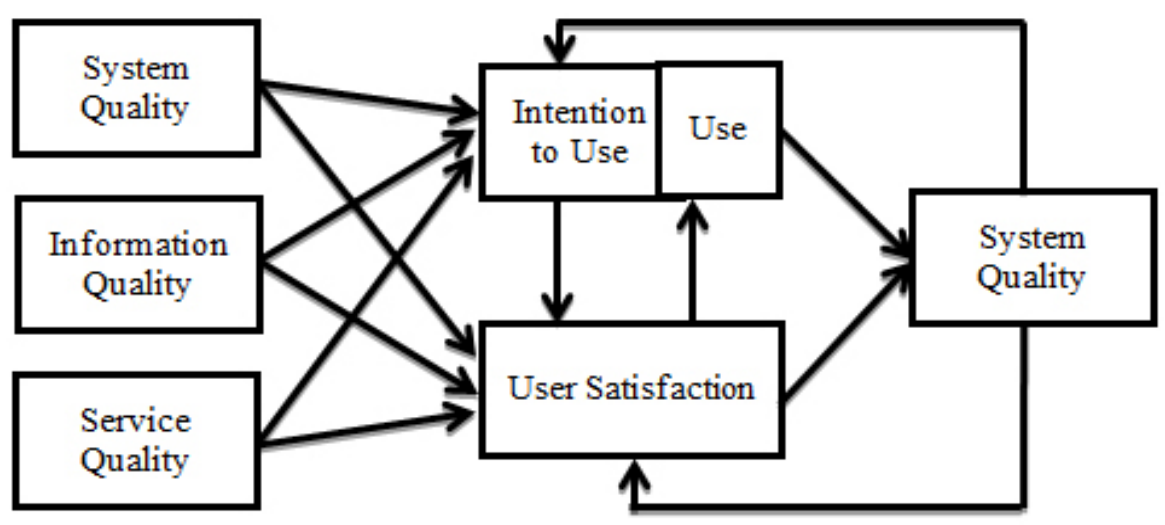

Figure 2. DeLone \& McLean Modified Information System Success Model (2003)

Livari (2005) tested the DeLone and McLean (1992) model on accounting information system in the Oulu City Council, Finland. A field study was carried out using longitudinal data of 78 people (sample) who were the main users of the system. Perceived System Quality was found to be a significant predictor for Use and User Satisfaction; Perceived Information Quality affected User Satisfaction but did not affect Use; while Use and user Satisfaction were not found to affect each other reciprocally. The individual impact was significantly influenced by User Satisfaction, but not by Use. Wu and Wang (2006) conducted a study using the DeLone and McLean model approach by developing a construct to measure the success of the Knowledge Management System (KMS) using three variables, namely User Satisfaction, Perceived KMS Benefits and Perceived KMS Use. It was conducted on 50 companies in Taiwan that implemented KMS. Data analysis was performed using SEM with the help of the LISREL program. The results showed that 5 out of 7 hypotheses were acceptable, while the two were rejected. Thus, the research was empirically proving and supporting the DeLone and McLean model (1992).

Pristiyanti (2016) conducted a study using the Delone \& Mclean model (2003) on the Go-Jek application by interviewing 173 respondents. The results showed that both System Quality and Service Quality had positive effects on User Satisfaction and the Intention to Use. At the same time, Information Quality had a positive effect (but insignificantly) on User Satisfaction but not influenced the Intention to Use. Some studies above showed that the context of the use of voluntary and mandatory information systems gives different results, which may be affected by the nature of the use of the information system.

\section{METHODS}

This research was a case study of the status of research subjects concerning a specific or typical phase of the whole personality. Research subjects in case studies can be individuals, groups, institutions, and society (Nazir, 2003). This study used quantitative data, in the form of numbers, to test hypotheses between variables (Sugiarto, 2000). The research subject observed was PT Grundfos Indonesia. Case studies aim to examine intensively the background and interaction of the environment and social units that are the subject of research. The study was conducted in the period August to October 2017 and was limited to evaluating the implementation of 1 Office. 
The population in this study was all employees at PT. Grundfos Indonesia, while the samples were employee representatives in each section using 1 Office as a tool for work and communication. The sampling was by using a non-random selection approach, namely purposive sampling of 70 users of 1 Office of 122 employees of PT. Grundfos Indonesia, the rest in which were those in the production division, admin, and contract employees who did not use the 1Office system.

The method used in this research was the componentbased Structural Equation Modeling (SEM) or Partial Least Square (PLS). The PLS was selected because it was widely used for causal-predictive analysis and was suitable for prediction and theory development as in this study. Besides, the PLS did not require a lot of assumptions and the data used did not have to be multivariate normally distributed and the number of the sample did not have to be large (Ghozali, 2008). Because the number of samples used in this study was small $(<100)$, the PLS was used as an analysis tool. The SmartPLS version 3 program was used to conduct testing with component-based SEM or PLS.

The analysis was carried out in two stages, namely the assessments using both measurement and structural models, respectively. The measurement was for assessing the validity and reliability of the data with parameters including convergent validity, discriminant validity, composite reliability, and Cronbach's Alpha. Subsequently, the structural model was done to predict the relationship between latent variables, and then closed with the interpretation of results and conclusions. Evaluation of the two models is shown in Table 1.

The selection of variables in this study adopted the concept of DeLone and McLean (1992 and 2003) and other studies, taking into account the appropriateness of the mandatory nature of the system used by PT Grundfos Indonesia. These variables included Service Quality - KL, System Quality - KS, Information Quality - KI, use - PG, User Satisfaction - KP, and Net Benefit - NB. All of these variables then were checked about their influence and correlation using the Likert scale $1-5$. Those indicating variables were attached in Table 1. Based on the five variables, the following hypotheses are developed:
H1a : KL has a positive effect on PG
$\mathrm{H} 1 \mathrm{~b}$ : KL has a positive effect on KP
$\mathrm{H} 2 \mathrm{a}$ : KS has a positive effect on $\mathrm{PG}$
$\mathrm{H} 2 \mathrm{~b} \quad$ : KS has a positive effect on KP
$\mathrm{H} 3 \mathrm{a}$ : KI has a positive effect on PG
$\mathrm{H} 3 \mathrm{~b}$ : KI has a positive effect on KP
$\mathrm{H} 4 \mathrm{a}$ : PG has a positive effect on KP
$\mathrm{H} 4 \mathrm{~b}$ : PG has a positive effect on NB
H5 : KP has a positive effect on NB

Table 1. Evaluation of measurement and structural models

\begin{tabular}{|c|c|}
\hline CRITERIA & EXPLANATION \\
\hline Evaluation of Measurement Model & (Measurement Model/Outer Model) \\
\hline Convergent validity & $\begin{array}{l}\text { The correlation value of the item score with the construct score must be more than } \\
0.70\end{array}$ \\
\hline \multirow[t]{3}{*}{ Discriminant validity } & $\begin{array}{l}\text { Cross loading: It is expected that each block of indicators has a higher loading for } \\
\text { each measured latent variable, compared to indicators for the others. }\end{array}$ \\
\hline & $\begin{array}{l}\text { AVE (average variance extracted) value must be more than } 0.50 \text { and it is expected } \\
\text { that the square value of AVE must be higher than the correlation value between } \\
\text { latent variables. }\end{array}$ \\
\hline & $\begin{array}{l}\text { The square root value of AVE must be higher than the correlation value between } \\
\text { constructs. }\end{array}$ \\
\hline Composite reability & $\begin{array}{l}\text { Measured with internal consistency and Cronbach's alpha, and the value must be } \\
\text { above } 0.60 \text {. }\end{array}$ \\
\hline Evaluation of Structural Model & (Structural Model/Inner Model) \\
\hline R square & $\begin{array}{l}\text { The results of the R square of } 0.67,0.33,0.19 \text { for endogenous latent variables } \\
\text { in the structural model indicate that the model is good, moderate, and weak, } \\
\text { respectively. }\end{array}$ \\
\hline Estimated path coefficient & $\begin{array}{l}\text { The estimated value for the path correlation in the structural model must be } \\
\text { significant. The significance value is obtained by bootstrapping method }\end{array}$ \\
\hline
\end{tabular}

Source: Ghozali (2008) 
The research framework that adopted the Delone and Mclean (2003) success model was a type of reflective research model, which assumed that the covariance between measurements was explained by variants as manifestations of their latent constructs. Also, the indicators were effect indicators. The direction of causality was from the construct to measurement indicators so the construct explained the measurement variants (Jogiyanto and Abdillah, 2009). The mindset and hypothesis that have been formulated can be seen in Figure 3.

\section{RESULTS}

\section{Respondents' Profiles}

Seventy questionnaires were distributed, and 60 or $85 \%$ of the total respondents returned. The description of the respondent's profile consisted of their name, gender, department, length of work, age, last education, as summarised in Table 2. Describing their profiles was needed to explain their background, as the sample in this study.

\section{Outer Model}

The analysis of the outer model aimed to examine the relationship between latent variables and their indicators, or it can be said that the outer model defines how each indicator relates to the latent variable or, in other words, whether the loading factor indicator for each construct meets convergent validity. A value that has a high level of validity if it has a loading factor value greater than 0.60 (Ghozali, 2008). The loading factor measurement results can be seen in Figure 4 . The loading factor measurement was done based on the outer loading data for each indicator by each latent variable to ensure that the results are following predetermined provisions. It can be seen that the indicator in each latent variable has a value higher than 0.6 so that the results of the indicator have met the requirements.

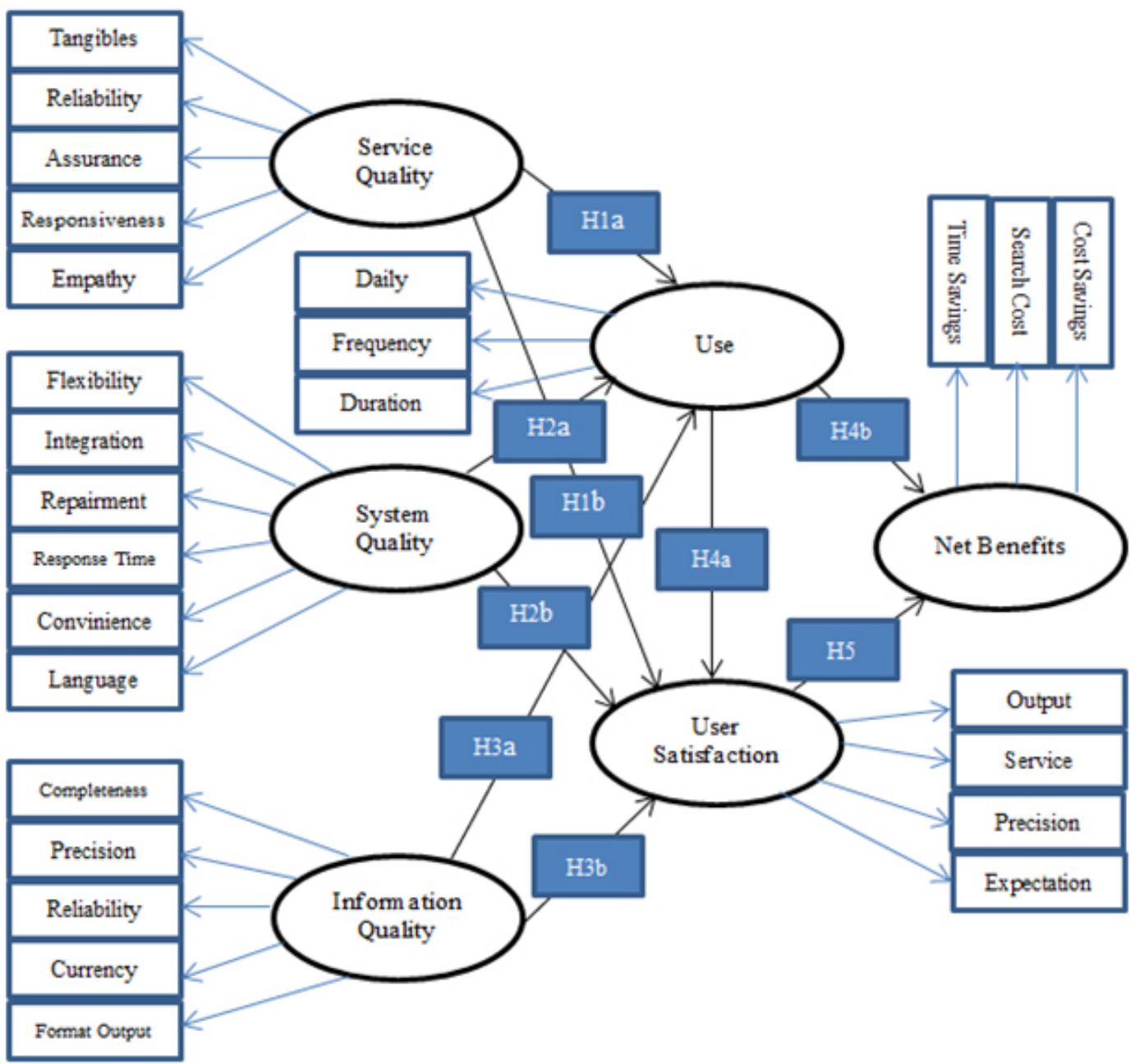

Figure 3. Framework, hypotheses and variables (DeLone and McLean Model, 2003) 
Table 2. Profiles of respondents at PT Grundfos Indonesia

\begin{tabular}{lcc}
\hline Profiles of respondents & Number & Percentage (\%) \\
\hline Sex & 34 & \\
Male & 26 & 56.67 \\
Female & & 43.33 \\
Age & 17 & \\
$21-30$ & 31 & 28.33 \\
$31-40$ & 10 & 51.67 \\
$41-50$ & 2 & 16.67 \\
$>50$ & & 3.33 \\
Work experience & 37 & \\
$1-5$ & 10 & 61.67 \\
$5-10$ & 13 & 16.67 \\
$>10$ & & 21.67 \\
Level of education & 13 & \\
SMA & 8 & 21.67 \\
DIII & 34 & 13.33 \\
S1 & 5 & 56.67 \\
S2 & & 8.33 \\
\hline
\end{tabular}

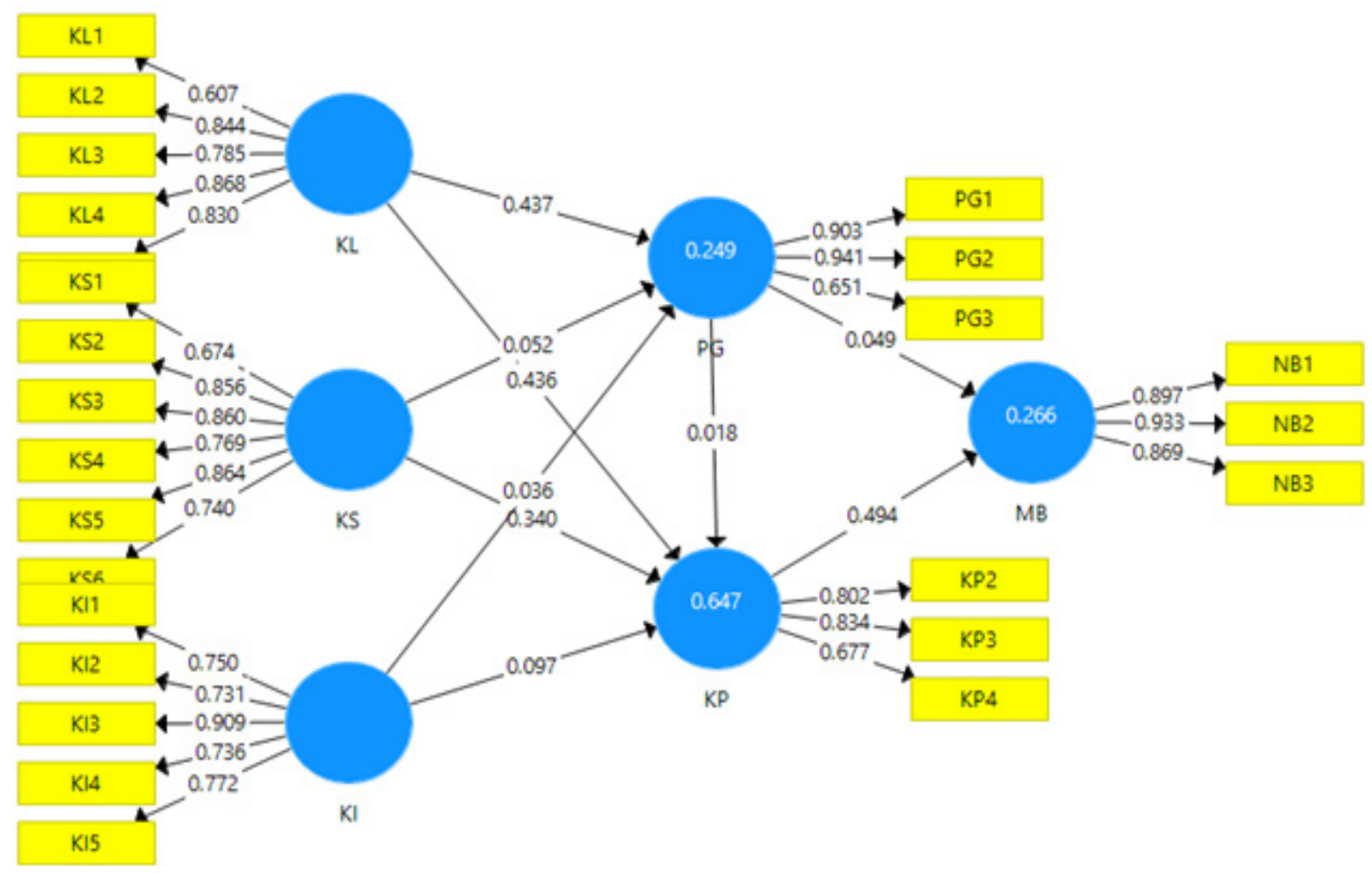

Figure 4. Results of the loading factors measurement model 
The next stage of research was to conduct a reliability test to measure the internal consistency of the instrument using two methods, namely Cronbach's alpha and composite reliability. Cronbach's alpha was used to measure the lower limit of a construct's reliability value, while composite reliability measured the actual construct's reliability value. Table 3 shows that the results obtained for Cronbach's alpha and composite reliability have met the requirements, which were greater than 0.6 so that the lower limits of the construct reliability value and the construct reliability value have been considered to meet the requirements and were reliable.

\section{Inner Model}

The next evaluation was the structural model or the inner model. The first evaluation of the inner model is seen from the value of the R-squared. Table 4 shows that the R-squared value for user satisfaction was 0.647 , meaning that the percentage of the influence of system quality, Information Quality and Service Quality on User Satisfaction was $64.7 \%$, while the remaining $35.3 \%$ was influenced by other factors. The R-Squared value for Use is 0.249 , which means that the percentage of influence on the System Quality, Information Quality and Service Quality was $24.9 \%$ while the remaining $75.1 \%$ was influenced by other factors. The R-Squared value for Net Benefits is 0.266 , which means that the percentage of influence on User Use and Satisfaction was $26.6 \%$ while the remaining $73.4 \%$ was influenced by other factors.
The next stage was the assessment of the goodness of fit to measure the feasibility of a set of observations that show a low level of difference between the observed value and the value expected in the model (Jogiyanto, 2007), which can be determined through the Q2 value. Q2 value has the same meaning as the coefficient of determination (R-squared) in the regression analysis, where the higher the $\mathrm{R}$ square, the fitter the data. From the $\mathrm{R}$ square value in Table 4, the Q2 value can be calculated as follows:

$$
\begin{aligned}
\text { Q2 value } & =1-(1-0.647) \times(1-0.249) \times(1-0.266) \\
& =1-(0.353 \times 0.751 \times 0.734) \\
& =0.805
\end{aligned}
$$

From the calculation results, it is known that the Q2 value of 0.805 , means that the diversity of research data that can be explained by the structural model developed in this study was $80.5 \%$. Based on these results, the structural model in the study already has a good level of goodness of fit.

Structural model or also called inner model describes the correlation between latent variables based on substantive theory. Assessing inner models can be done by looking at structural models consisting of the correlation between hypotheses and latent constructs in the research model. Standard errors, path coefficients, and t-statistics values can be obtained by using the bootstrapping method on SmartPLS.

Tabel 3. Results of reliability test

\begin{tabular}{lcc}
\hline Construct & Cronbach's Alpha & Composite Reliability \\
\hline Service quality & 0.848 & 0.893 \\
System quality & 0.883 & 0.912 \\
Information quality & 0.840 & 0.887 \\
User satisfaction & 0.664 & 0.816 \\
Use & 0.789 & 0.877 \\
Net benefit & 0.883 & 0.927 \\
\hline
\end{tabular}

Table 4. R-squared test results

\begin{tabular}{lcc}
\hline Construct & R-Squared & Adjusted R-Squared \\
\hline User satisfaction & 0.647 & 0.622 \\
Use & 0.249 & 0.209 \\
Net benefits & 0.266 & 0.241 \\
\hline
\end{tabular}


Table 5 shows the test results of the path coefficient values between variables. The original sample, which was a non-standard beta score, was used to see the predictive nature of the independent variable on the dependent variable. The sample mean was the average value of the sample generated from the iteration process, the standard deviation was a standard deviation level of a sampling distribution tin a measurement or estimation method; and t-statistics was a parameter of the significance of predictive effects between latent variables measured by the type of hypothesis (Jogiyanto, 2007). If t-statistics is higher than the standard deviation values, then it can be concluded that the hypothesis is influential. In this study, the confidence level was used at $95 \%$, then the t-table value for the one-tailed hypothesis was $>1.64$.

Table 5 shows that the hypotheses H1a, H1b, H2b and H5 have t-statistics values higher than 1.64, which proves that all four hypotheses have a significant effect, while the hypotheses H2a, H3a, H3b, H4a and H4b have no significant effect. From these results, it can be concluded that Service Quality influences Use and User Satisfaction, System Quality influences User Satisfaction, and User Satisfaction is beneficial to the company. Bootstrapping results using SmartPLS (Figure 5).

\section{Interpretation of Hypothesis Testing Results}

Service Quality has a positive effect on Use

Good Service Quality increases convenience in using the 1Office system daily, the length of time, and frequency of use. The results showed the highest predictor was the responsive services provided by the service desk, so users felt comfortable using the 1Office system every day for a long time and often. These results supported previous researches by Rosyadi (2017) and Aginowo (2017).

Service quality has a positive effect on user satisfaction

The strongest predictor of Service Quality is fast service, which is indicated by users who are satisfied with the speed of service provided by the IS service desk for 7 days $\times 24$ hours. A predictor that still need to be improved is User, who has not felt satisfied with the best service quality. These results support previous researches by Rosyadi (2017) and Aginowo (2017).

System Quality has no positive effect on Use

System Quality does not have a positive effect on Use, indicating that User is not convinced that the 1Office system can be used anywhere and anytime (flexible) and integrated into other systems so that it requires loading time and error recovery, which also require time. This is what cannot be accepted by the user. This is reflected by the results obtained that the use of a system that can be used anywhere and anytime (flexible) becomes the weakest indicator and influences the results of the hypothesis. This result is in line with previous research by Budiyanto (2015).

System Quality has a positive effect on user satisfaction

System Quality has a significant positive effect on User Satisfaction, indicating that System Quality is considered good and gives satisfaction to the users. If System Quality is good, then the user will feel comfortable using the 1Office system and in reusing it. These results support previous researches by Seddon (1997), Livari (2005), Subramanian (2005), Baskoro (2015) and Huse (2017).

Table 5. Path Coefficients

\begin{tabular}{lccccc}
\hline Hypothesis & Construct & Original Sample & Sample Mean & Standard Deviation & t-statistics \\
\hline H1a & LQ - U & 0.437 & 0.431 & 0.199 & 2.195 \\
H1b & LQ - US & 0.436 & 0.447 & 0.150 & 2.907 \\
H2a & SQ - U & 0.052 & 0.079 & 0.267 & 0.195 \\
H2b & SQ - US & 0.340 & 0.330 & 0.175 & 1.941 \\
H3a & IQ - PG & 0.036 & 0.022 & 0.231 & 0.157 \\
H3b & IQ - US & 0.097 & 0.096 & 0.127 & 0.767 \\
H4a & U - US & 0.018 & 0.020 & 0.086 & 0.204 \\
H4b & U - NB & 0.049 & 0.058 & 0.138 & 0.358 \\
H5 & US - NB & 0.494 & 0.508 & 0.161 & 3.071 \\
\hline
\end{tabular}




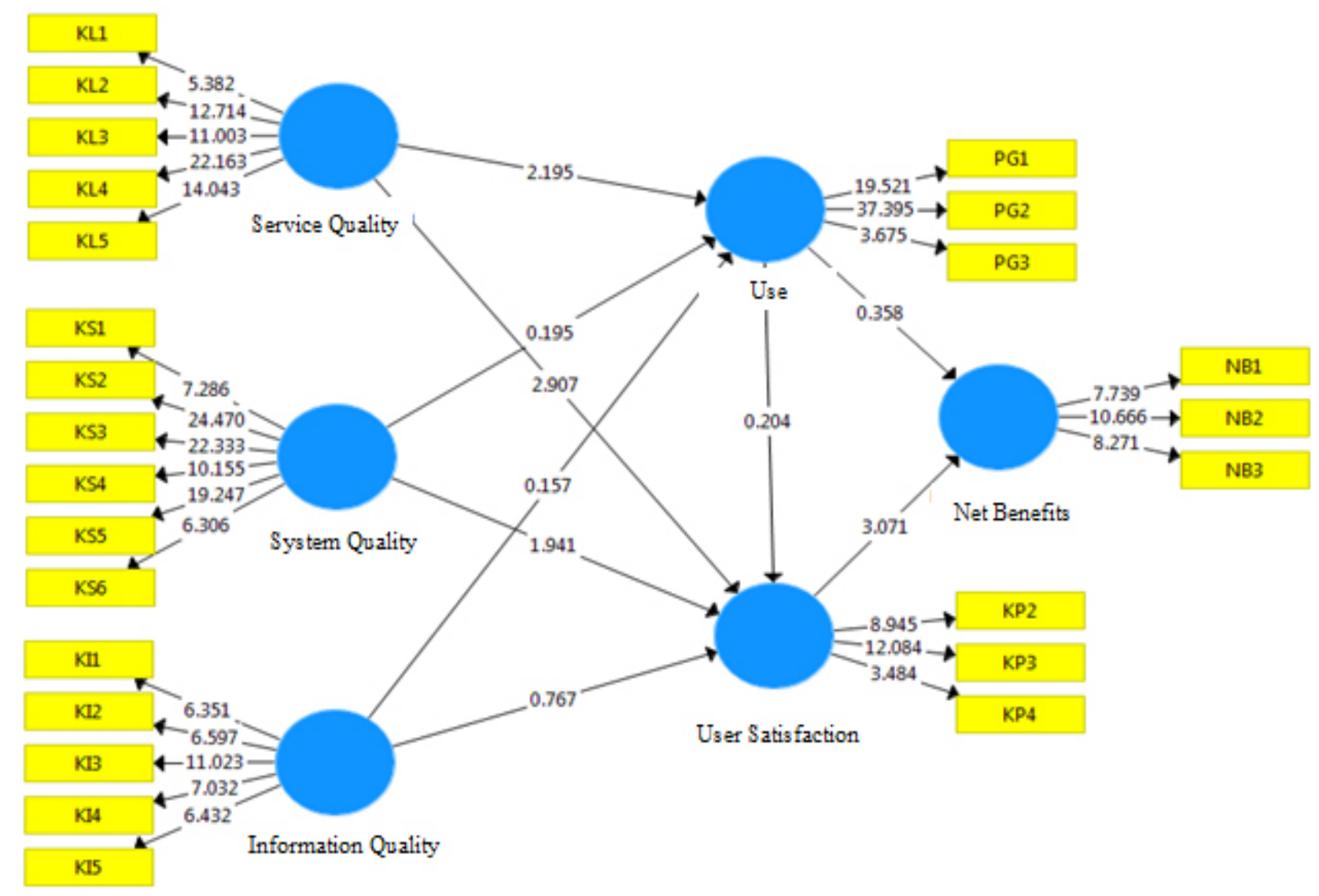

Figure 5. Bootstrapping results using SmartPLS

Information Quality has no positive effect on Use

Information Quality reflects that the completeness and accuracy of the information in the form of output still do not support the Use of the 1Office system. The results of this study are in line with previous studies by Roldan and Leal (2003), Livari (2005), Budiyanto (2009), Prastiwi (2014) that the implementation of information systems in mandatory and voluntary contexts has different results, especially in the measurement of the variable Use.

Information Quality has no positive effect on User Satisfaction

The results showed that Information Quality does not have a positive influence on User Satisfaction. This is because there are difficulties in processing data so that it lets the users not to be satisfied with the Information Quality. The results of this study are in line with previous studies by Radityo and Zulaikha (2007), Roldan and Leal (2003).
Use has no positive effect on User Satisfaction

The results showed that the Use of the system had no impact on User Satisfaction. This result is in line with previous researches by Radityo and Zulaikha (2007) and Budiyanto (2009), who identified that the Use of mandatory information systems cannot be used to measure User Satisfaction. It is because User Satisfaction is an attitude that arises from within and does not occur due to coercion as in the implementation of mandatory information systems.

Use has no positive effect on Net Benefits

System Use, seen from the intensity, length of time of use, and frequency of use, does not have a significant impact on the performance of Net Benefits. The results of this study do not support the success model of information systems developed by Delone and Mclean (2003). However, these results are in line with previous studies by Livari (2005), Budiyanto (2009), Oktavia (2016) which found that there was no effect between actual Use and individual impact. 
These results support previous researches conducted by Qudus (2013), Kurniawan (2016), and Lazaroni (2017), which indicated that User Satisfaction with the 1Office system has fulfilled the needs and helped the user's work. The system also has a good impact on individual and organisational performance which directly or indirectly increases Net Benefits for the organisation through increased work accuracy, work process efficiency, effectiveness at work, and overall cost savings. The results of this study are also consistent with the research of DeLone and McLean (2003) which showed that User Satisfaction is a significant predictor of Net Benefits.

\section{Managerial Implications}

The results of this study have implications that the use of the 1Office system at PT Grundfos Indonesia, which includes 24-hour and 7-day services, has been going well and is very helpful for users in using the 1Office system so that it gets a positive response by the users. It also has a direct impact on User Satisfaction so that users feel comfortable in using the system because they get guaranteed assistance from the Grundfos IS service desk. But the thing to note is that users do not believe that the 1Office system uses the latest hardware and software, so it is considered necessary to make comparisons with other companies for the same market segment or comparison of other companies that have implemented similar systems to 1Office. It aims to convince users of 1Office that this implemented system is the latest technology.

The System Quality has fulfilled the expectations of 1Office users for a high-quality system that has good system integration so that it produces a fast response time in the process, requires time acceptable by users in making errors, using language that is easily understood by users. But the flexibility of the system needs to be improved, which is reflected in the results of research that indicate that the user still feels that the flexibility of the system is still not maximum. Thus, PT Grundfos Indonesia can submit this recommendation to the Grundfos headquarter to maximise the facilities of the 1Office system such as by letting the system applicable on smartphones to facilitate the user and can support the flexibility of the system.

\section{Conclusions}

Service Quality has a significant positive effect on Use and User Satisfaction, means that users appreciate the services provided by Grundfos IS service desk, which results in their satisfaction with the 1Office system. System Quality has a significant positive effect on User Satisfaction but does not have a positive effect on Use because the system is mandatory and must be used by the users even though the user still does not feel the maximum quality of the 1Office system. Information Quality does not have a positive influence on Use and also on User Satisfaction. These results provide evidence that users find it difficult to utilise Information Quality generated from the 1Office system, thus dissatisfying the users.

The Use does not have a significant positive effect on Net Benefits, means that even though the intensity of the Use of the 1Office system is high and is used every day by users, it does not indicate that it will have a positive impact on net benefits for the company, due to the mandatory nature of the system. But User Satisfaction has a significant positive effect on Net Benefits. Thus, these results indicate that users have been satisfied with the 1Office system that is supported by Service Quality, while Service Quality has a positive impact on user groups, organisations, suppliers, and customers at PT. Grundfos Indonesia.

\section{Recommendations}

It is recommended for further researches to expand the scope of research by involving Grundfos organisations in other countries such as Grundfos Singapore, Grundfos Malaysia, Grundfos Thailand, and Grundfos Philippines so that it is expected to provide the diversity of respondents due to differences in work culture and IT infrastructure that supports in the countries. Moreover, further researches should add dimensions of each construct so that testing of the construct can be done in detail. This will complete the results of each construct's research and theories so that references regarding information systems research will be more extensive. 


\section{REFERENCES}

AginowoA.2017.Pengujiankarakteristik organisasi dan karakteristik individu yang dapat memengaruhi kesuksesan Sistem Informasi Akuntansi Badan Layanan Umum Daerah [tesis]. Yogyakarta: Universitas Gadjah Mada.

Ajzen I. 1991. The theory of planned behavior. Organizational Behavior and Human Decision Processes 50(2):179-211. https://doi. org/10.1016/0749-5978(91)90020-T.

Baskoro RBW. 2015. Evaluasi Sistem Business Intelligent Mengunakan Model Kesuksesan Sistem Model Kesuksesan Sistem Informasi Delone dan Mclean di PT Hero Supermarket Tbk [tesis]. Yogyakarta: Universitas Gadjah Mada.

Budiyanto 2009. Evaluasi Kesuksesan Sistem Informasi Dengan Pendekatan Model Delone dan Mclean (Studi Kasus Implementasi Billing System Di RSUD Kabupaten Sragen) [tesis]. Surakarta: Universitas Sebelas Maret.

Davis FD. 1989. Perceived usefulness, perceived ease of use, and user acceptance of technology. MIS Quarterly. 13(3):319-340. https://doi. org/10.2307/249008.

DeLone WH, McLean ER. 1992. Information systems success: the quest for the dependent variable. Information Systems Research 3(1):60-95. https://doi.org/10.1287/isre.3.1.60.

DeLone WH, McLean ER. 2003. The delone and mclean model of information system success: a ten-year update. Journal of Management Information Systems 19(4):9-30. https://doi.org/10.1080/074 21222.2003.11045748.

Ghozali I. 2008. Structural Equation Modeling Metode Alternatif dengan Partial Least Square Ed ke-2. Semarang: BP-Undip.

Huse VD. 2017. Analisis Kesuksesan Aplikasi Gojek dari Perspektif Pengguna Masyarakat Surabaya Menggunakan Information System Success Model (ISSM) [tesis]. Surabaya: Institut Teknologi Sepuluh Nopember.

Janson MA, Subramanian A. 1996. Packaged software: selection and implementation policies. INFOR 34(2): 133-151. https://doi.org/10.1080/031559 86.1996.11732298.

Jogiyanto. 2007. Model Kesuksesan Sistem Teknologi Informasi. Yogyakarta: Andi.

Jogiyanto. 2007. Sistem Informasi Keperilakuan. Yogyakarta: Andi.
Jogiyanto HM, Abdillah W. 2009. Konsep dan Aplikasi Partial Least Square (PLS) Untuk Penelitian Empiris. Yogyakarta: Penerbit BPFE.

Kurniawan I. 2016. Evaluasi Kesuksesan Online Monitoring Sistem Perbendaharaan Dan Anggaran Negara Dengan Pendekatan DeLone \& McLean Information System Success Model [tesis]. Surabaya: Institut Teknologi Sepuluh Nopember.

Lazaroni I. 2017. Analisis Kesuksesan "Sistem Informasi Manajemen Kinerja Pegawai Secara Elektronik (E-Performance) Pada Dinas Tenaga Kerja Kota Surabaya"Menggunakan Information System Success Model (ISSM) [tesis]. Surabaya: Institut Teknologi Sepuluh Nopember.

Livari J.2005. An empirical test of the delone and mclean model of information system success. Data Base for Advances in Information Systems 2(36):8-27. https://doi.org/10.1145/1066149.1066152.

Oktavia DD. 2016. Kesuksesan implementasi SIMDA untuk meningkatkan akuntabilitas pengelolaan keuangan pemerintah. Jurnal Politeknik Negri Malang 2(1):1-6. https://doi.org/10.18382/ jraam.v2i1.65.

O’Brien, James A. 2006. Pengantar Sistem Informasi Perspektif Bisnis dan Manajeria Ed Ke-12. Jakarta: Salemba Empat.

Perry B. 2006. Organisational Managementand Information Systems, CIMA Learning System 2007. New York: The McGraw-Hill Companies.

Prastiwi E. 2014. Pengaruh implementasi sistem informasi akuntansi terhadap penggunaan dan kepuasan pengguna di institut pertanian bogor[tesis]. Bogor: Institut Pertanian Bogor.

Qudus SIA. 2013. Analisis Penerapan Kesuksesan Sistem Teknologi Informasi Sikompak Pada Pdam Di DIY [tesis]. Yogyakarta: Universitas Gajah Mada.

Radityo D, Zulaikha. 2007. Pengujian model delone and mclean dalam pengembangan sistem informasi manajemen (kajian sebuah kasus). Jurnal dan Prosiding SNA - Simposium Nasional Akuntansi 2(10):1-25.

Roldan JL, Leal A. 2003. A Validation Test of an Adaptation of the Delone and McLean's Model in Spanish EIS Field. Seville: Idea Group Publishing.

Rosyadi MI. 2017. Analisis Kesuksesan Aplikasi Uber Driver Dari Prespektif Pengguna Masyarakat Kota Surabaya DenganPendekatan ModelDelone 
Dan McLean. Undergraduate [tesis]. Surabaya: Institut Teknologi Sepuluh Nopember.

Seddon PB. 1997. A respecification and extension of the delone and mclean model of IS success. Information Systems Research 8(3):240-253. https://doi.org/10.1287/isre.8.3.240. 